\title{
Depremler ve Afet Yönetimi: 30 Ekim 2020 İzmir Depremi Örneği
}

\author{
Öznur Akduman \\ Tekirdağ Namık Kemal Üniversitesi, Sağlık Yüksekokulu, Acil Yardım ve Afet Yönetimi Anabilim Dalı, Tekirdağ, \\ Türkiye.
}

\section{Özet}

Afetler meydana geldiği toplum üzerinde fiziksel, ekonomik, sosyal ve çevresel açıdan olumsuz sonuçlar doğuran, söz konusu toplumun normal yaşam seyrini tamamen veya kısmen durduran ve toplumu dişarıdan bir yardıma muhtaç hale getiren doğa, teknoloji ve insan kaynaklı olayların oluşturduğu sonuçlardır. Ülkemizde yoğun nüfuslu kentler, plansız kentleşme, mühendislik hizmeti almamış yapılaşma, hızlı sanayileşme, afet risklerini azaltmaya yönelik örgütlenmenin olgunlaşmamış olması ve risklerin yönetilememesi gibi faktörlere bağlı olarak birçok afet yaşanmaktadır. Afetlerle ilgili yapılan bilimsel çalışmalar dikkate alındığında; depremler üzerinde meydana gelme sıklığı ve yüksek hasar potansiyeli nedeniyle yoğunlaşılmıştır. Afet ve acil durum yönetimi başkanlığı (AFAD) tarafından hazırlanan raporlara göre ise ülkemizin yaklaşık \%92 si deprem tehlikesine sahiptir. Sadece 2020 yılında meydana gelen en ölümcül depremler sıralamasında ülkemiz, yaşanan 2020 İzmir depremi ile 1. Sıradadır. 30 Ekim 2020 tarihinde yaşanan İzmir depremi ülkemizde ve Yunanistan'da toplam 119 kişinin ölümüne ve 1053 kişinin ise yaralanmasına neden olmuștur. 30 Ekim 2020 İzmir depremi gibi yaşadığımız tüm depremlere baktığımızda yönetim uygulamalarının yoğun olarak kriz yönetimine dayandığı görülmektedir. Bu çalışmanın amacı; İzmir ilinde deprem tehlikesinin ve deprem risk yönetiminin öneminin vurgulanması, tüm sektörlerin katılımıyla modern afet yönetim sisteminin sürdürülebilir bir şekilde uygulanmasına yönelik araştırmalar ortaya konulmaktadır.

Anahtar kelimeler: Afet, Afet yönetimi, Deprem, İzmir depremi, Risk Analizi.

\begin{abstract}
Disasters are the result of natural, technological and human-caused events that have physical, economic, social and environmental consequences in the society in which they are challenged, completely or partially stop the normal course of life of this society and make the society in need of outside help. In our country, cities with low population are experiencing a first-class disaster due to factors such as unplanned urbanization, lack of engineering services, rapid industry, maturation of examples to reduce disaster risks, and risk management. Considering the scientific studies conducted on disasters; it was destroyed due to the frequency of occurrence of earthquakes and the high potential of damage.According to the reports prepared by the disaster and emergency management directorate (AFAD), about $92 \%$ of our country has a depreciation. In the ranking of the most deadly that occurred only in 2020, our country is the 1st with the 2020 Izmir earthquake. Is in line. The Izmir earthquake on October 30, 2020 killed a total of 119 people and injured 1053 people in the country and Greece. In our view of all the earthquakes we experienced, such as the October 30, 2020 Izmir earthquake, it is seen that management practices are heavily based on crisis management.The aim of this study is to highlight the importance of depreciation and depreciation risk management in Izmir province and to conduct research on the sustainable implementation of a modern disaster management system with the participation of all sectors.
\end{abstract}

Keywords: Disaster, Disaster management, Earthquake, Izmir earthquake, Risk Analysis.

*Corresponding author: Address: Faculty of Engineering, Department of Civil Engineering Sakarya University, 54187, Sakarya TURKEY. E-mail address: caglar@ sakarya.edu.tr, Phone: +902642955752 Fax: +902642955601 


\section{Giriş}

Dünya nüfusunun \%50'si deprem tehlikesi olan alanlarda yaşamaktadır. 1900'lü yıllardan itibaren dünya nüfusunun yaklaşık 1,2 milyondan fazlasının, deprem kaynaklı afetler nedeni ile hayatını kaybettiği tahmin edilmektedir [34]. Deprem: Tektonik kuvvetlerin veya volkan faaliyetlerinin etkisiyle yer kabuğunun kırılması sonucunda ortaya çıkan enerjinin, sismik dalgalar hâlinde yayılarak geçtikleri ortamları ve yeryüzünü kuvvetle sarsması olayıdır [46]. Yaygın olarak depremler fay kaynaklarındaki ani enerji boşalımları ile meydana geleceği gibi; volkanik aktiviteler, göktaşı çarpmaları, toprak kaymaları, nükleer bomba patlamaları ve daha başka tetikleyici unsurlar nedeniyle de meydana gelebilir [47]. Kısa sürede büyük coğrafyaları etkileyebilen, binlerce insanın ölümüne yaralanmalarına yol açabilen depremler afet türleri arasında en etkili olanları arasındadır [48].

Alp orojenik dağ kuşağında yer alan ülkemiz, Doğu Anadolu ve Kuzey Anadolu ana fayları ve çok sayıda yerel fay üzerinde bulunmaktadır [4]. Yüzölçümümüzün ise \%92'i deprem tehdidi altındadır [6]. Nüfusumuzun yaklaşık \% 71'i birinci ve ikinci derece deprem bölgelerinde bulunmaktadır [5]. Dahası insanların yaşadığı alanlarda birinci geçim kaynağı genellikle toprak olduğu için tarım arazilerinin büyük bir kısmı deprem bölgeleri üzerinde yer almaktadır. Bu arazilerin yaklaşık \%42'si birinci dereceden, \%24'ü ikinci dereceden ve \%18'i ise üçüncü dereceden deprem bölgesi üzerindedir. Bu sayısal değerler bize olası bir depremin yaşanması halinde etkisinin ne kadar büyük olacağını göstermektedir [7]. Uluslararası Afet Veri Tabanı (EM-DAT) tarafından edinilen bilgilere göre; ülkemizde 1900-2020 yılları arasında yaşanan depremler sonucu can kaybı sayıs1 94,013 kişi olarak raporlanmıştır. Aynı tarihler için Dünya ülkelerinde yaşanan depremler sonrası verilen can kayıplarına bağlı yapılan sıralamada ülkemiz 9. sırada yer almaktadır. Depremler, verilen can kaybının yanında büyük miktarlarda ekonomik zararlara da neden olmaktadır. Yine 1900-2020 yılları arasında yaşanan depremlerin ekonomik zararı ise 39,5 milyar dolar olarak tahmin edilmiş ve ülkemiz dünyada yaşanan depremlerin verdiği ekonomik zararlar sıralamasında 6. Sırada yer almıştır [49]. Sıkça yaşadığımız depremlere baktığımızda ülkemizin sahip olduğu aktif depremsellik ortadadır. 2020 yılında dünyada yaşanan depremler incelendiğinde ise toplam can kaybının 198 kişi olduğu belirtilmiş ve bu can kayıplarının 160'1 ülkemizde yaşanmıştır. 30 Ekim 2020 İzmir Depremi nedeni ile 117 vatandaşımız hayatını kaybetmiş, 1032 vatandaşımız yaralanmıştır. İzmir depremi 2020 yılının en ölümcül depremi olarak kayıtlara geçmiştir [8;28]. Depremler yer kürenin değiştirilemez bir davranış biçimidir. Günümüzde depremlerin nerelerde olabileceği ve karşılaşacağımız tehlikenin şiddeti tahmin edilebilmekte birlikte, depremin ne zaman ve ne büyüklükte olacağı bilinmemektedir. Fakat insani hatalarımız düzeltilebilir ve görülen zararlar en aza indirgenebilir. Bu amaçla afetlere neden olan insan kaynaklı hatalarımızın neler olduğunun tespit edilmesi, öğrenilmesi ve edinilen tecrübeler ışığında bir daha tekrarlanmaması için önlemler alınmalıdır. Bu çalışmada tüm afetler gibi depremler içinde uygulanabilir risk yönetiminin üzerinde durulmuş, yaşanan olayların afet boyutlarına çıkmasını önlemeye dayalı ve depremlerin yıkıcı etkilerini azaltmaya dayalı kısa bilgiler sunmaktadır.

\section{Kavramsal Çerçeve}

\subsection{Depremler nasıl oluşur}


Dünyamızın çekirdeğinin sıcaklığı yaklaşık 4000 santigrat derece civarında ve yoğunluğunun 5,5 $\mathrm{kg} / \mathrm{m} 3$ olması nedeniyle çekirdek, manto ve yerkabuğuna doğru eriyik halde bulunur. Çekirdeğin sıcaklığının çok fazla olması etrafını saran magmayı hareketlendirir ve dünyamızın merkezinden dışarıya doğru enerji akışı meydana gelir [1]. Yüzeydeki ve yüzeye yakın olan plakalar bu enerji akışı ile hareket eder. Böylelikle birbirinden kopar veya birbirine temas eder. Bu temas ile plakaların bazıları; birbirini iterken bazıları birbirlerine yaklaşır. Dünyamızın zaman içinde yaşadığı bu hareketlilik ile birçok büyük ve çok sayıda küçük farklı levha adı verilen kara parçaları oluşmuştur. Büyük Levhalar: Pasifik levhası; Kuzey Amerika levhası, Güney Amerika levhası, Avrasya levhası, Afrika levhası, Hindistan-Avustralya levhası, Antarktika levhası. Bu levhaların dışında aynı zamanda birçok da küçük levhalar bulunmaktadır. Küçük Levhalar: Anadolu levhası, Kokos levhası, Karayip levhası, Nazka levhası, Arap levhasıdır [3]. Oluşan bu levhalar zamanla hareketlilik kazanır ve bir süre sonra çarpışır. Ortaya çıkan enerji yer yüzeyinde bulunan faylanım noktalarında sarsıntılara neden olur. Bu faylanım noktalarında beklenmedik bir anda ortaya çıkan enerji sonucunda meydana gelen sismik dalgalanmalar ve bu dalgaların yeryüzünü sarsması ile depremler meydana gelir [2].

\section{2. İmir'in Kentleşmesi}

Kentleşme kavramı ülkemizde 2. Dünya savaşından sonra hızla artan kırsal nüfusun, yaşanan ekonomik geçimsizlikler nedeni ile kentlere göç etmesi ile ortaya çıkmıştır. Zamanla göçlerin yoğunluk kazanması ile kentlerde büyük nüfus kitleleri oluşmuştur. Göçün yoğunluğu ve yönü ekonomik ve sosyal gelişmelerin yaşandığı bazı illere kaymıştır. Bu değişikliklerin etkisi ile illerde kentleşme hızı artmış ve kentin fiziki yapısını da değiştirmiştir. 1950'li yıllardan itibaren artan nüfus, tarımın modernleşmesi, ekonominin gelişmesi, hızlı sanayileşme, eğitimin yaygınlaşması gibi faktörler kentleşme sürecine ivme kazandırmıştır [15].1965 yıllarından sonra hızlanarak büyük endüstrilerin kurulması ise iç göç için ayrı bir çekim gücü oluşturmuştur [16]. Böylelikle İzmir kentinde bulunan yapılar yoğun göç dalgası nedeniyle gelen insanlara yetememiş ve barınma sorununu ortaya çıkartmıştır. İnsanların çoğu kent merkezlerinde ev ya da apartman dairesi alacak maddi olanaklara sahip olamamış ve yakın gelecekte alma ihtimalleri de oldukça düşüktür. $\mathrm{Bu}$ nedenle mekân sorunları için kendi çözümlerini üretmek zorunda kalmışlardır. Kentte göç edenlerin ucuz konut ihtiyaçlarının devlet tarafından karşılanamayınca geliri düşük göçmenler inşaat izni olmaksızın illegal olarak işgal edilmiş hazine arazileri üzerinde gecekondular inşa etmişlerdir [17]. İnsanlar geçinebilmek için güvenliklerini geri planda bırakarak gecekondu ve daha ilerleyen zamanlar da ise kalitesiz inşaat malzemesi kullanılan, mühendislik hizmeti almamış dahası bilgi ve deneyim bakımından eksik çalışanlarca inşa edilmiş yapılarda yaşamaya başlamışlardır [16].

Günümüz İzmir'i ise; 2020 y1lı itibari ile 30 ilçeye, 1.297 mahalleye ve 4.394 .694 nüfusa sahiptir.[40]. Kentleşmenin plansız şekilde oluşturulmasının sonuçları; yaşanan afetlerde kendini göstermiştir.

\subsection{Izmir'in Deprem Potansiyeli}

İzmir ilinin sismoloji arşivleri incelendiğinde, geçmişten günümüze önemli can ve mal kaybına neden olan pek çok deprem yaşanmış olduğu görülmektedir. [9;10;11;12].İzmir ili ve çevresi, Batı Anadolu açılma sisteminin bir sonucu olan graben yapılarının ve bunu yönlendiren ikincil 
dereceli doğrultu atımlı fayların etkisi altındadır [13].İzmir ve çevresi için yapılan yüksek sismik tehlike alanları sıralandığında; Deprem Bölgesi içindeki Midilli Adası civarı 1.; Dikili, Urla, Seferihisar, İzmir, Torbalı, Bayındır, Ödemiş, Buldan ve Denizli-Honaz civarı 2.; Kınık Simav arası ile Söke-Denizli arası 3.; Savaştepe civarı, Selendi-Uşak arası, Eşme civarı ve Söke-Çine arasındaki alanlar 4. dereceden deprem tehlikesi içermektedir [13;14;42]. İzmir ili ve çevresi fay zonlarının büyüklüğü ve aktifliği yönünden ülkemiz de üçüncü sıradadır [41].Bu bilgiler İzmir'de yaşam alanlarının; bölgenin deprem riskini, sismik aktivitenin hareket şeklini ve zemin özelliklerini göz önünde bulundurularak oluşturulması için gereklidir.

\subsection{Ekim 2020 İzmir Depremi}

30 Ekim 2020 tarihinde merkez üssü Ege Denizi Seferihisar açıklarında; Kandilli Rasathanesi ve Deprem Araştırma Enstitüsü verilerine göre 6.9 büyüklüğünde, İzmir'de Afet ve Acil Durum (AFAD) verilerine göre ise 16,54 km derinde, 6,6 büyüklüğünde, bir deprem meydana gelmiştir. Deprem, İzmir ilinin birçok farklı merkezinde hissedilmiş, fay hatlarının yoğun olduğu Bayraklı ilçesinde ağır hasarlara neden olmuştur. Depremin ana şokunu takip eden ve 3 gün içerisinde büyüklükleri 1.0 ile 5,1 arasında değişen, 43 tanesi 4.0'den büyük olan 1286 artçı deprem yaşanmıştır. Türkiye ve Yunanistan'da tsunami oluşumları gözlemlenmiştir. 30 Ekim 2020 İzmir Depreminde; Türkiye için 117 ölü, 1.034 yaralı, 15.000 evsiz kayıtlara geçerken, Yunanistan'da; 2 ölü ve 19 yaralı kişi olduğu belirtilmiştir [13;21]. Deprem sonrasında sarsıntının yoğun hissedildiği alanlar uzman ekiplerce mimari ve yönetmelikler doğrultusun da incelenmiştir. Yapılan değerlendirmelerde yapılar; hasarsız, az-orta-ağır hasarlı, yıkık ve acil yıkılacak yapılar olarak sınıflandırılmıştır. Toplamda 183.484 adet yapıda hasar tespit çalışması yapılmış, bunların İzmir ili için toplam yıkılan yapı sayısı 71, acil yıkılacak ve ağır hasarlı yapı sayısı ise 653 olarak belirtilmiştir [13;18;43].

Depremlerin büyüklükleri ölçülmesi için; öncelikle ivme değeri bilinmelidir. İvme değeri, yer sarsıntısı hızının zamana bağlı olarak değişim oranını vermektedir. Ülkemizde Afad'a ait 129 adet ivme ölçer bulunmaktadır. Şekil 3.’te görüldüğü gibi; İzmir-Seferihisar depreminin diş merkez mesafesinin $120 \mathrm{~km}$ içerisinde yer alan ana şoku kaydeden 33 adet kuvvetli yer hareketi kayıt istasyonu bulunmaktadır [13; 19;23;26].

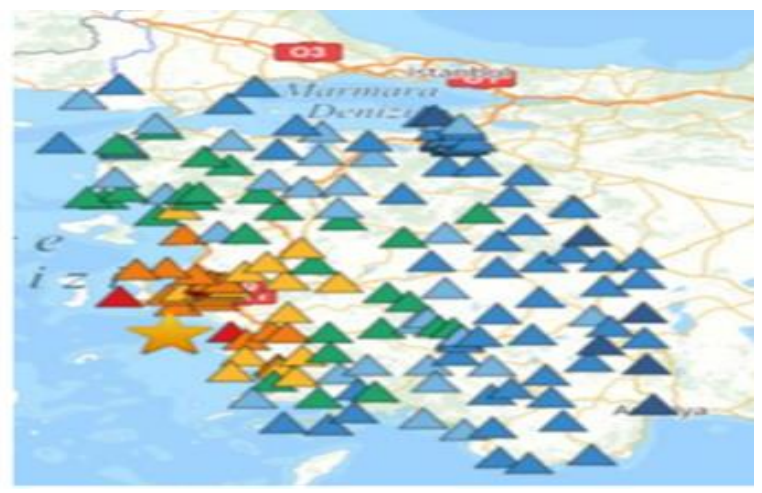

Şekil 3. Yaşanan Deprem ve Artçıların bulunduğu coğrafyaya yakın yer hareketi kayıt istasyonları[13].

Tablo 1' de 30 Ekim 2020 İzmir Depreminin ivmeölçer istasyonları ve ölçülen yer ivmesi (PGA) değerine dair bilgiler verilmiştir [19;24]. 
Tablo 1. Bölgedeki ivmeölçer istasyonlar ve ölçülen ivme değerleri [20].

\begin{tabular}{|cclcccc|}
\hline & İSTASYON & & & \multicolumn{3}{c|}{ PGA [g] } \\
Kodu & İl & İlçe & Uzaklı $[\mathrm{km}]$ & K-G & D-B & U-D \\
3536 & İzmir & Seferihisar & 35 & 0.050 & 0.081 & 0.032 \\
0905 & Aydın & Kuşadas1 & 43 & 0.183 & 0.147 & 0.081 \\
3523 & İzmir & Urla & 49 & 0.082 & 0.065 & 0.038 \\
3533 & İzmir & Menderes & 51 & 0.075 & 0.047 & 0.038 \\
3528 & İzmir & Çeşme & 58 & 0.120 & 0.152 & 0.078 \\
3519 & İzmir & Karşıyaka & 69 & 0.153 & 0.112 & 0.035 \\
3513 & İzmir & Bayraklı & 72 & 0.108 & 0.097 & 0.045 \\
\hline
\end{tabular}

Bina hasarlarının en fazla görüldüğü İzmir'in merkez Bayraklı ilçesinde AFAD’ın iki adet deprem izleme istasyonu yer almaktadır [13;20] .

Tablo 2. Bayraklı İlçesinde Bulunan Deprem İzleme İstasyon Bilgileri [13;20].

\begin{tabular}{|cccc|}
\hline İstasyon $(\#)$ & Vs30 $(\mathrm{m} / \mathrm{sn}$.) & Zemin Türü & Merkez üssüne uzaklık $(\mathrm{km})$ \\
3513 & 196 & C (Alüvyon zemin) & 72 \\
3514 & 836 & A (Kaya zemin) & 73.39 \\
\hline
\end{tabular}

Bayraklı ilçesindeki iki deprem izleme istasyonunun deprem anı maksimum yer ivmesi (PGA) ölçüm değerleri incelenmiştir. Birbirine çok uzak olmayan ve farklı karakterdeki zeminlere oturan bu iki istasyondaki İvme-Zaman Grafikleri şekil 4. verilmiştir [13;26].
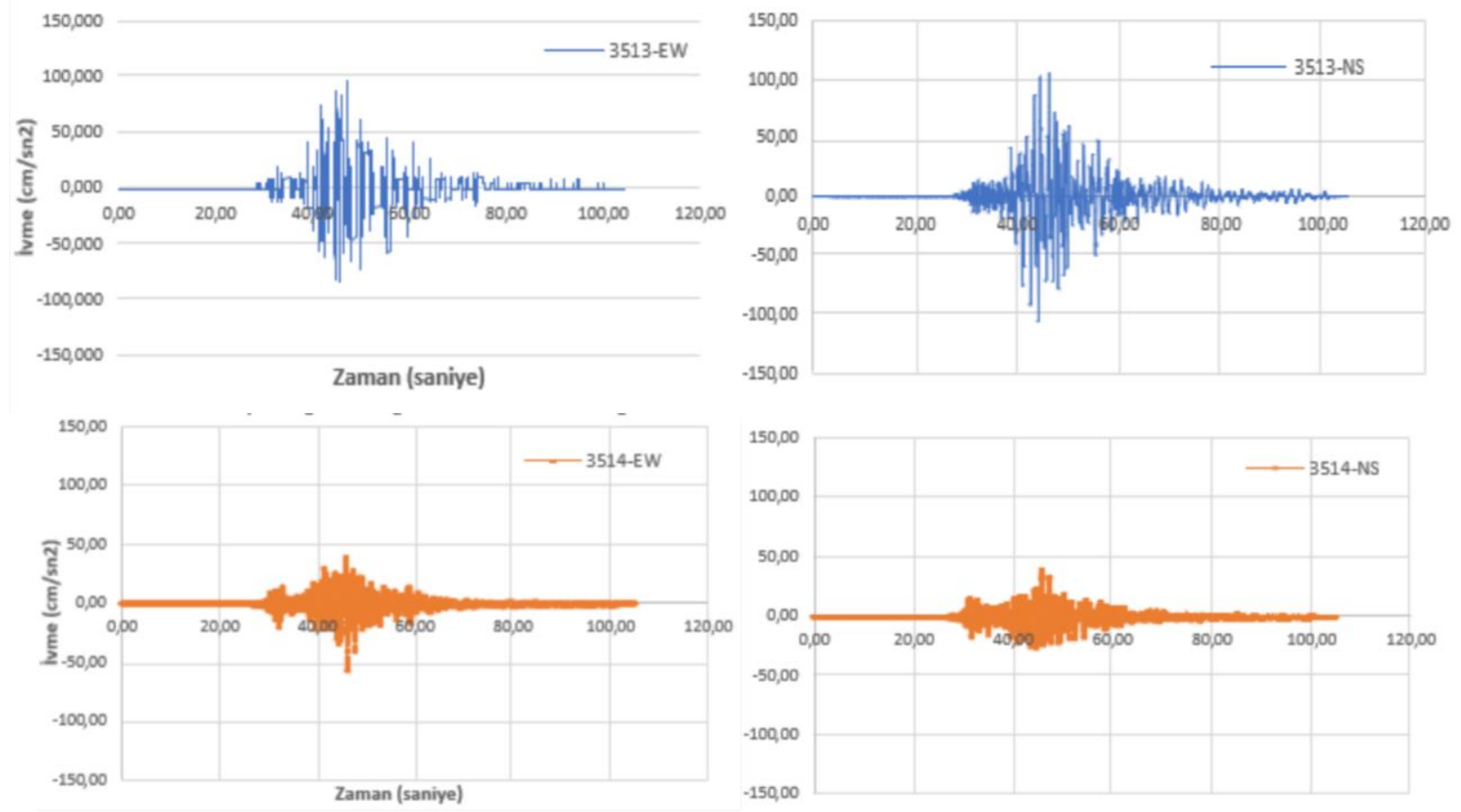

Şekil 4. Bayraklı ilçesinde bulunan 3513ve 3514 İstasyonlarının İvme-Zaman Grafikleri[21].

Bayraklı ilçesinde bulunan ve 30 Ekim 2020 İzmir Depremi'nin ivme ölçümü yapan 3513 numaralı istasyonda ve 3514 numaralı kayıt istasyon grafikleri incelendiğinde; PGA ölçüm sonuç 
değerlerinin arasında anlamlı farklılık olduğu görülmektedir [21;22;23]. 3513 numaralı izleme istasyonunda ölçülen deprem büyüklüğünün; yer yüzeyine ulaşırken enerjisinin azalması beklenirken, tam tersi arttığ görülmektedir. Bu farklılık 3513 numaralı istasyonda zemin büyütmesi olduğunu göstermiştir. $\mathrm{Bu}$ durum özellikle kalın alüvyon birikimi gibi gevşek zeminlerin bulunduğu jeolojik yapılarda deprem dalgalarının genliklerinde meydana gelen artış ile ortaya çıkar[24;25;13].30 Ekim 2020 tarihinde meydana gelen depremin etkilerinin, depremin odağına yaklaşık 70 km uzaklıktaki Bayraklı ilçesinde meydana gelmesi, sıklıkla bölgenin üzerinde oturduğu yumuşak alüvyon zemine bağlanmaktadır[24;25;13].Tuncel (2021), İzmir'in kiy1 kısımlarında kaya dolgusunun az olduğu yerlerde alüvyon ve sediman kısımlarında yüksek olduğunu ve bu bölgede yaşanan yer sarsıntılarının ana kayadan yüzeye kadar olan zemin tabakasının deprem etkisini arttırıcı etkiler oluşturduğu sonucuna ulaşmış ve zemin büyütmesinin varlığını ortaya koymuştur[38].Ancak 30 Ekim 2020 İzmir Depremin neden olduğu hasarların büyüklüğü sadece zemin etkisi ile açıklanamaz[21;22;23]. İzmir depreminde yapıların hasar görme ve yıkılma nedenlerini anlamaya yönelik hazırlanan raporlarda; hasarlı ve yıkılan yapıların tasarım hatalarına, tasarlanan yapıların uygulama anındaki hatalara ve yapıların inşası sonrası kullanıcı kaynaklı hatalara maruz kaldığı belirtilmiştir [22;28].

Tablo 3. İzmir Depremi sonrası saha gözlemlerine dayalı hasarlı ve yıkılan yapılara yönelik kurum ve üniversitelerin deprem raporları [22].

\begin{tabular}{|c|c|c|c|}
\hline $\begin{array}{lr}30 & \text { Ekim } \\
2020 & \text { İzmir } \\
\text { Depremi }\end{array}$ & Tasarım Hataları & Uygulama Hataları & $\begin{array}{l}\text { Uygulama Sonrasi } \\
\text { Hatalar }\end{array}$ \\
\hline $\begin{array}{l}\text { BTU Raporu } \\
\text { [23] }\end{array}$ & 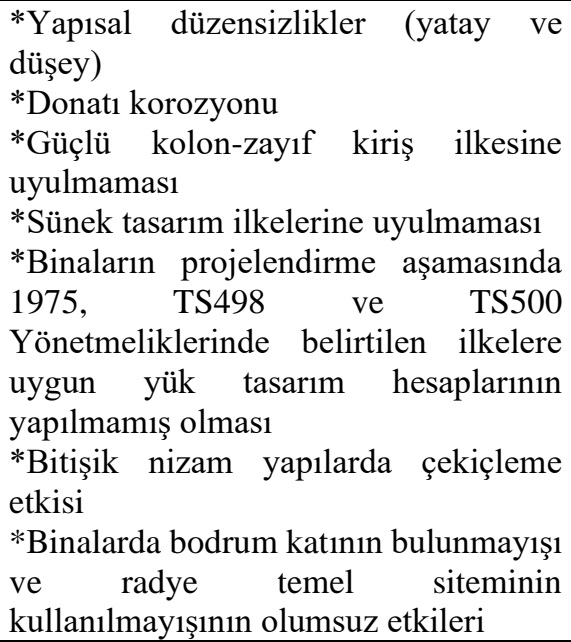 & $\begin{array}{l}\text { *Donatı detaylandırılmasının } \\
\text { döneminin Yönetmeliğine bile } \\
\text { uygun yapılmamış olması } \\
\text { *Sahadaki uygulamanın statik } \\
\text { projeye uygun olmaması } \\
\text { *Kolon-kiriş en birleşim } \\
\text { bölgelerinde enine donatı } \\
\text { bulunmaması }\end{array}$ & $\begin{array}{l}\text { *Tasarım ve uygula } \\
\text { hatasına yönelik } \\
\text { tespitlerde öncelikle } \\
\text { binaya müdahale } \\
\text { olmadıysa } \\
\text { vurgusunun } \\
\text { bulunması } \\
\text { *Binaların taşıyıcı } \\
\text { sisteminde sonradan } \\
\text { tadilatlar } \\
\text { gerçekleştirilmiş } \\
\text { olması }\end{array}$ \\
\hline $\begin{array}{l}\text { ÇSB } \\
\text { Değerlendir } \\
\text { me } \\
\text { Raporu[24] }\end{array}$ & $\begin{array}{l}\text { *Tasarım (Yumuşak/ Zayıf Kat, Plan } \\
\text { Düzensizliği ve Ağır Çıkma) *imar } \\
\text { (Binaların Yerleşim Şekli, Bitişik } \\
\text { Nizam Bağlı Çekiçleme, Yeterli } \\
\text { Dilatasyon Bırakılmaması) }\end{array}$ & $\begin{array}{l}\text { *Malzeme (Beton Kalitesi, } \\
\text { Dayanım } \\
\text { *Donatı Uygulamaları (Yetersiz } \\
\text { Donatı Miktarı ve Çapının } \\
\text { Kullanılması, } \\
\text { olmaması) } \\
\text { *Yapınının } \\
\text { işçiliği, kalı häzensiz demir } \\
\text { kolona oturmaması) }\end{array}$ & - \\
\hline
\end{tabular}




\begin{tabular}{|c|c|c|c|}
\hline $\begin{array}{l}\text { GÜ } \\
\text { Raporu[25] }\end{array}$ & 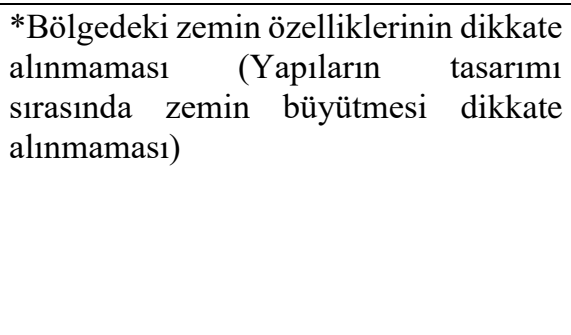 & 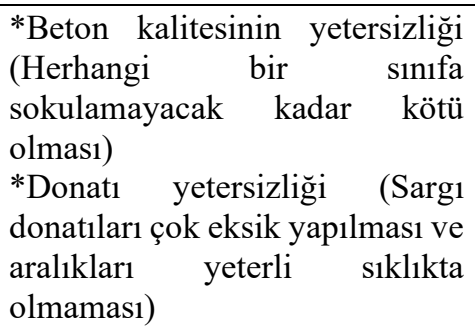 & $\begin{array}{l}\text { * İinsiz tadilatlar } \\
\text { (Proje dışı izinsiz } \\
\text { tadilatlar yapılarak } \\
\text { işyeri yapılması } \\
\text { amacı ile duvar yıkımı } \\
\text { ve buna bağll olarak } \\
\text { da yumuşak kat } \\
\text { oluşumu) }\end{array}$ \\
\hline $\begin{array}{l}\text { İMO } \\
\text { Raporu[26] }\end{array}$ & $\begin{array}{l}\text { *Giriş katının duvarlardan arındırılmış } \\
\text { olarak sadece kolonlardan } \\
\text { oluşturulması veya ticari kaygılar ile } \\
\text { giriş katın dolgu duvarlarının yok } \\
\text { edilmesi uygulamaları olması }\end{array}$ & $\begin{array}{l}\text { *Toptan göçen binalarda düşük } \\
\text { beton kalitesi, çoğunlukla düz } \\
\text { yüzeyli donatı kullanımı ve } \\
\text { sargılama donatısının } \\
\text { (etriyelerin) uygun şekilde } \\
\text { kullanılmaması }\end{array}$ & $\begin{array}{l}\text { *Yaygın olarak zemin } \\
\text { katlardaki dolgu } \\
\text { duvarların } \\
\text { kaldırılarak dükkân } \\
\text { ya da süpermarket } \\
\text { olarak kullanılması } \\
\end{array}$ \\
\hline $\begin{array}{l}\text { İTÜ } \\
\text { Raporu[9] }\end{array}$ & $\begin{array}{l}\text { * Düzensiz taşıyıcı sistemler } \\
\text { * Çekiçleme etkisi } \\
\text { * Yetersiz kesit boyutları } \\
\text { * Kısa kolonlar } \\
\text { * Yumuşak zayıf katlar } \\
\text { * Mimari proje kaynaklı sorunlar } \\
\text { *Yerel zemin koşullarının olumsuz } \\
\text { etkisi }\end{array}$ & $\begin{array}{l}\text { *Yetersiz malzeme özellikleri } \\
\text { *Donatı korozyonu } \\
\text { *Kolon-kiriş birleşim } \\
\text { bölgelerindeki sorunlar } \\
\text { *Sünek olmayan donatı } \\
\text { detaylandırması, sargı etkisinin } \\
\text { yetersizliği }\end{array}$ & $\begin{array}{l}\text { *Taşıyıc1 olmayan } \\
\text { bölme duvarlarının } \\
\text { kaldırılması, düşeyde } \\
\text { sürekliliklerin } \\
\text { bozulması }\end{array}$ \\
\hline $\begin{array}{l}\text { ODTÜ } \\
\text { Raporu[19] }\end{array}$ & $\begin{array}{l}\text { * Düzgün bir yapısal taşıyıcı sistem ve } \\
\text { deprem kuvvetlerinin doğru akışını } \\
\text { sağlayacak sürekli bir aks sistemi } \\
\text { oluşturulmamış olması }\end{array}$ & $\begin{array}{l}\text { *Kolon alt uçlarında donatı } \\
\text { korozyonu olmasi. }\end{array}$ & -- \\
\hline
\end{tabular}

İzmir Depremi sonrası saha gözlemlerine yönelik oluşturulan raporların genelinde ;yıkılan ve ağır hasar gören yapıların tamamına yakının inşaları sırasında; bina yönetmeliklerine tam olarak bağlı kalınmadığ 1 , beton üretiminde herhangi bir standart gözetilmediği ve düşük dozajlı olarak üretildiği tespit edilmiştir. Depremde yıkılan yapılar incelendiğinde, bu yapıların çok fazla etkilenmesinde 2000 yılından önce inşa edildiği ve inşa sırasında düz donatı ve çok düşük kalitede beton kullanılmasının neden olduğu belirtilmiştir. Bununla beraber yapıların zemin etütlerinin sağlıklı yapılmaması, zemin katlarındaki zayıf kat oluşumu, taşıyıcı elemanlarda yapılan kontrolsüz tahribat ve tadilatlar ve binaların yıllar içinde yaşadığı korozyon ve diğer etkilerle yıpranması gibi nedenlerin bir veya birkaçını barındırması yapılarda kısmi göçmelere ve binaların yıkılmasına sebep olmuştur [29;22].

\subsection{Afet Yönetimi}

Ülkemizin geçmiş depremselliği ve yakın zamanlarda yaşanan depremler sonrası yapılan incelemelerle uzman kişilerin, üniversite ve kurumların hazırlamış olduğu raporları 1şı̆̆ında; Depremlerde görülen zararları azaltmak için öncelikle Şekil 5 'tede verilen afet yönetiminin tüm basamaklarının eksiksiz yapılmasının esas olduğu

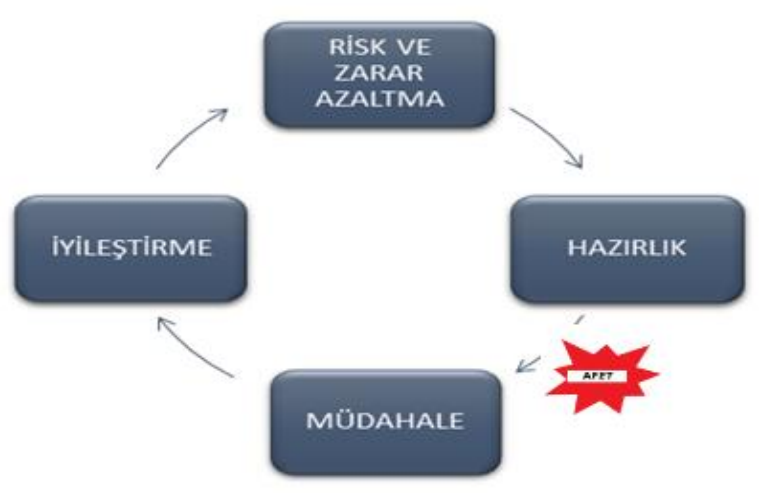
belirtilmiştir [35]. 
Şekil 5. Bütünleşik Afet Yönetimi Sistemi [35].

Deprem afeti için afet yönetimi döngüsü yapılırken; yaşanan deprem yöresinin öncelikle deprem tehlikesi bilinmeli, uygun tehlike yönetimi ve insanların yaşam alanlarını etkileyecek yerlerde ise risk yönetimi yapılmalıdır. Tüm özel ve kamu kuruluşlarının kendi üzerlerine düşen, şehrin tüm afet tehlikelerine bağlı olarak afet öncesi, sırası ve sonrasında yapması gereken uygulamaları bilmeli ve yerine getirmeleri gerekmektedir. Geçmişte yaşanan deprem kaynaklı kayıplara bağlı olarak; şehir içi alanların deprem tehlikesinin yüksek olduğu alanlardan, düşük olduğu alanlara kaydırılmalıdır. Bununla beraber deprem tehlikesinin yüksek olduğu alanlarda yapıların yönetmeliklere uygun olarak iyileştirilmesi sağlanmalıdır. Depremlerden önce tüm risk ve zarar azaltma çalışmaları yapılmalıdır.

\subsubsection{Risk ve zarar azaltma çalışmaları;}

- Öncelikle yaşadığımız alanların hangi tehlikeleri barındırdığını bilmeliyiz. Bu tehlikelerin meydana gelmesi halinde savunmasızlıklarımızı tanımlamalıyız.

- Ülkemizin büyük bir kısmı deprem tehlikesi altındadır. Yaşam alanlarımızın ve insan faaliyetlerimizin tamamına yakını aktif deprem bölgelerinde yoğunlaşmıştır. Bu yüzden bizler risklerimizi yönetmeliyiz. 'Depremler ne zaman olacak?' sorusuna cevap aramak yerine nasıl zarar görebilirliğimizi azaltabiliriz sorularına cevap bulmalıyız. Bu nedenle deprem tehlikesi yüksek alanlarda yaşamamaya özen gösterilmelidir.

- Bu alanlarda yaşıyorsak, yapısal ve yapısal olmayan zarar azaltma çalışmaları yapmalıyız.

- Mevzuatların yaşadığımız alanın afet tehlikelerine uygun hazırlanmış olması gerekir.

- Yaşadığımız alanlardaki afetlere dair eğitim ve bilinçlendirme eğitim ve tatbikatlara katılım sağlamalıdır.

- Risk altındaki kritik yapılarımızı, altyapılarımızı ve tarihi eserlerimizi güçlendirmeliyiz [35;36;37].

\subsubsection{Hazırlık;}

-Yaşanılan alanın afet tehlikelerine uygun olarak tahmin ve erken uyarı sistemleri oluşturulmalı ve bu sistemlere halkında kolaylıkla ulaşması, anlayabileceği düzeyde sunulması sağlanmalıdır.

-Uygun önlem alma, acil durum, kurtarma, tahliye planları hazırlanmalı ve bunlar sik sık tüm kurum ve kuruluşlara, çalışanlara ve halka, eğitimler ve tatbikatlarla benimsetilmelidir.

-Yaşanabilecek zararlara yönelik tahmini kaynak sağlanmalı ve aktif gönüllülük sistemi oluşturulmalıdır [35;36;37].

\subsubsection{Müdahale;}

- Haber alma, Ulaşım, Arama Kurtarma, İlkyardım, Toplu Yardımlar yapılmalıdır.

- İkincil afetlere hazırlıklı olunmalı.

- Doğru ve güvenilir bilgiler ile basın ve yayın ilişkileri kurma.

-Afetzedelere ve çalışan kişilere; yiyecek, su, ilaç gibi yaşamsal ihtiyaçları, güvenlik ve çevre sağlığı, barınma ihtiyaçları karşılanmalıdır.[35;36;37].

\subsubsection{Iyileştirme;}


- Yaşanan afetler sonrası enkaz kaldırma, tamir ve güçlendirme, sağlık, psikolojik yardımlar ve iyileştirme programları ve yeniden yapılandırmalarının uygulandığı aşamadır.[35;36;37].

\section{Tartışma ve Sonuç}

Ülkemizde ve dünyada yaşanan son depremlerin sonuçlarına bakıldığında; sismik bölgelerde, risk yönetimi, bilinçlendirme ve güçlendirmeye yüksek önem verilmesi gerektiğini ortadadır[39]. Özmen (2012), yaptığı çalışmada ülke topraklarının ve nüfusumuzun büyük bir kısmının deprem bölgesinde yer aldığı ve yaşanan depremlerde yıkılan binaların ve birçok can kayıplarının sık sık yaşandığını belirtmektedir[28]. Ülkemizde yaşanan depremler sonrası verilen kayıplarda, afet yönetimi çalışmalarının yeterli düzeye ulaşamamış olduğu görülmektedir. Depremlerin sık sık yaşanması ülkemizin deprem gerçeği ile yaşamayı öğrenmesi gerekliliğini ortaya koymaktadır. Ülkemizde yaşanan depremler sonrası ortaya çıkan zarar olgusunun fazla olmasının ; depremlerden daha çok yanlış tasarlanan, denetimsiz, uygunsuz inşa edilen yapılar ve sadece krize odaklı afet yönetimi sistematiğinin uygulanıyor olmasına bağlı olduğu görülmektedir. Tunçel ( 2021) yılında İzmir bölgesinde yapmış olduğu çalışmasında bölge için jeolojik birimlerin çok değişken olması ve çok sayıda farklı uzunluktaki fayların etkisi ile dinamik parametrelerin karmaşık bir dağılım gösterdiği açıklayarak İzmir ilinin aktif sismik yapısına sahip olduğu belirtmiştir[38]. İzmir ili ve çevresindeki yüksek sismik enerji tehlikesinin varlığı bilinmesine rağmen; yapılarda kullanılan inşaat malzemelerinin niteliksiz ve eksik olması, mimari tasarımlarda ise ekonomik, fonksiyonel ve estetik kaygıların ön planda tutulması ve yapılan hesaplanma hatalarının varlığı ile yaşanan depremin sonuçları çok ağır olmuştur. Scawthorn ve Johnson (2000) yaptığı çalışmada; depremlerde Sünek olmayan betonarme yapılarda hasarların yüksek derecede olduğunu belirtmiştir. Çok sayıda aktif fay zonlarına sahip olan İzmir ve çevresi için depreme dayanıklı yapı ve inşa tasarım kriterlerini uyulması gerektiği ve esnek yapıların inşa edilmesi gerektiği açıktır. Yapılan çalışmalar sonucunda depremlerin engellenemeyeceği fakat vereceği zararlar en aza indirilebileceği, yani risklerin azaltılmasının yaşanabilecek zararlarları da azaltabileceğini göstermiştir. Bu çalışmalara göre yer seçimi, imar planı ve depreme dayanıklı yapılaşma kuralları (deprem yönetmelikleri), düzenli denettim ve bilinç düzeyi yüksek toplulukların oluşturulması gerekliliği ortaya koyulmaya çalışılmıştır. Bütün afetler gibi depremler için de tüm aşamalarının doğru uygulandığı bir afet yönetimi sistematiğinin oluşmasıyla; toplumumuzun sosyal, modern, ekonomik gereksinimleri ve sürdürebilir yapı hedeflerimiz karşılanacaktır.

\section{Katkı Belirtme}

Bu çalışmanın gerçekleşmesindeki desek ve katkılarından dolayı Doç. Dr. Ayşe Handan Dökmeci'ye ve Doç. Dr. Ahmet Afşin Kaya’ya teşekkürlerimi sunarım.

\section{Kaynaklar}

[1]Url-1:Levha Hareketleri (Plaka Tektoniği): Dünya Yüzeyini Oluşturan Plakalar Nelerdir? https://evrimagaci.org/levha-hareketleri-plaka-tektonigi-dunya-yuzeyini-olusturan-plakalar-nelerdir-

566(Son erişim:22.05.2021).

[2] Url-1:Deprem. Https://tr.wikipedia.org/wiki/deprem(Son erişim:30.10.2021). 
[3]Url-3:Dünya Deprem Haritas1: Dünyadaki Deprem Bölgeleri (Ülkeleri) ve Merkez Üsleri. https://www.milliyet.com.tr/egitim/haritalar/dunya-deprem-haritasi-dunyadaki-deprem-bolgeleri-ulkelerive-merkez-usleri-6306581. (Son erişim:22.05.2021).

[4]Elmas A. Türkiye'nin Tektonik Yapısının Gravite Verileri Kullanılarak Değerlendirilmesi. Mühendislik Bilimleri ve Tasarımı Dergisi, 2018;6(2), 258-264.

[5]Akıncıtürk N. Tasarımında Mimarın Deprem Bilinci. Uludă̆ Üniversitesi Mühendislik-Mimarlık Fakültesi Dergisi, 2003;Cilt 8, Sayı 1, 189.

[6]Pampanin S. "Towards the "Ultimate Earthquake-Proof" building: Development of an integratedlowdamage system. In Perspectives on European Earthquake Engineering and Seismology"2015;321335. Springer, Cham.

[7]Altın S. 6 Kasım 1992 İzmir Depremi Sonuçları Üzerine Bir İrdeleme. Teknik Dergi, 1993;4(4), 731742.

[8]Url-4:30 Ekim 2020 İzmir Depremi. (https://www.sozcu.com.tr/2020/gundem/2020de-depremden-193kisi-oldu-155i-turk-6109857/).

[9]Ergin K. Güçlü U. Uz Z. Türkiye ve civarının deprem kataloğu (M.S.11-1964). İTÜ, Maden Fakültesi, Arz Fiziği Enstitüsü yayınları, 1967;24, İstanbul.

[10]Pınar N. Lahn E. Türkiye depremleri izahlı kataloğu. Bayındırlık Bakanlığı, Yapı ve İmar İșleri Reisliği, 1952; 6, Ankara.

[11]Emre Ö. Özalp S. Doğan A. Özaksoy V. Yıldırım C. Göktaș F. İzmir Yakın Çevresinin Diri Fayları ve Deprem Potansiyelleri, Maden Tetkik ve Arama Genel Müdürlüğü. 2005

[12]Utku M. Kentleşmede Yapılaşma Alanlarının Deprem Riski ve Tehlikesi: İzmir Örneği, 2018.

[13]Afet ve Acil Durum Yönetimi (AFAD) Deprem Dairesi Başkanlığg1."30 Ekim 2020 Sisam Adası (İzmir Seferihisar Açıkları) Mw 6.6 Depremi Raporu” 2020.

[14]Utku, M, Özyalın, Ş, Utku, Z. İzmir Depremleri İzmir ve Çevresi nin Deprem Riski. Presented at the İzmir ve Çevresi’nin Deprem-Jeoteknik Sempozyumu (JEOTEKNIK-III), 2001; İzmir,

[15]Kılınç Z A , Bezci B. Kentleşme Gecekondu ve Hemşerilik. Akademik incelemeler Dergisi, 2011; 6(2), 232-344.

[16]Türkçü Ç, Gökmen H, Kaya İ D, Süer D, Neslian Onat N, Sönmez A, Günhan S. İzmir Özelinde Göç ve Yapılanmış Çevre. Gecekondulaşma Olgusu ,Toplu Konut Uygulamaları. (?).

[17]Yavuz HM. Islamic Political Identity in Turkey, Oxford University Press, 2003; New York.

[18]T.C. Çevre ve Şehircilik Bakanlığı Yapı İşleri Genel Müdürlüğü (ÇŞB), "30 Ekim 2020 İzmir Seferihisar Depremi(Mw=6.6) Genel Değerlendirme Raporu”, 2021.

[19] Orta Doğu Teknik Üniversitesi (ODTÜ). Deprem Mühendisliği Araştırma Merkezi.."30 Ekim 2020 Mw 6.6 Sisam Adası (İzmir Seferihisar Açıkları) Depremi Sismik ve Yapısal Hasara İlişkin Saha Gözlemleri” 2020.

[20]Url -5:İvme Verileri Https://tadas.afad.gov.tr .

[21] İstanbul Teknik Üniversitesi (İTÜ). “30.10.2020 İzmir Depremi Değerlendirme Raporu”. 2020.

[22] Özen R S, Korkmaz, SZ, Ecemiş A S. Mimari ve Strüktür Tasarım İlişkisinde Tekrarlanan Hatalar 2020 İzmir Depremi İzlenimleri. Ege Mimarlık, 2021; 2(110), 70-77.

[23]Bursa Teknik Üniversitesi (BTÜ). Deprem Mühendisliği Uygulama ve Araştırma Merkezi (DEPAR).“İzmir Depremi Değerlendirme Raporu”. 2020. Son Güncelleme 13.01.2021. https://depo.btu.edu.tr/ dosyalar/btu/Dosyalar/Rapor_Bursa.Teknik.Uni. Deprem.2020.10.30.pdf

[24]T.C. Çevre ve Şehircilik Bakanlığ́1 Yapı İşleri Genel Müdürlüğü (ÇŞB). "30 Ekim 2020 İzmir Seferihisar Depremi(Mw=6.6) Genel Değerlendirme Raporu” 2021.

[25]Gazi Üniversitesi Deprem Mühendisliği Uygulama ve Araştırma Merkezi 2021. "Seferihisar Açıkları (İzmir) Depremi Ön Değerlendirme Raporu”.2020. Son güncelleme 13 Ocak 2021. http://gazi.edu.tr/posts/ view/title/gazi-universitesi-deprem-muhendisligiuygulama-ve-arastirma-merkezi-seferihisaraciklari-

\%28izmir\%29-depremi-on-degerlendirmeraporu-256498 
[26]TMMOB İnşaat Mühendisleri Odası İzmir Şubesi (IMO). “30 Ekim 2020 Tarihinde Meydana Gelen İzmir Depremi Raporu”. 2020. Son güncelleme 20.02.2021,

[27]Altındal A, Konak N.“17 Ağustos 1999 Depreminde Yıkılan Binaların Mimari Hataları”.Sakarya Üniversitesi Fen Bilimleri Enstitüsü Dergisi, 2002;6(2).147-152.

[28]Özmen H, Mehmet İ, Bayram Ç. "23 Ekim ve 9 Kasım 2011 Van Depremleri Yapısal Hasar Değerlendirme Raporu”. 2015

[29]Çağlar N, Kırtel O, Vural İ, Sümer Y, Sarıbıyık A. 30 Ekim 2020. Mw 6.6 Ege Denizi Seferihisar (İzmir) Depremi İnceleme ve Değerlendirme Raporu. 2020; Sakarya Uygulamalı Bilimler Üniversitesi Deprem Çalışmaları Uygulama ve Araştırma Merkezi - Damer 11 Kasım 2020.

[30]Demirtaş R. İzmir İli, Menderes İlçesi, Değirmendere, Gümüldür ve Özdere Mahallelerinin Paleosismolojik ve Yüzey Faylanması Tehlike Zonu Açısından Değerlendirilmesi 2019;10.13140/RG.2.2.14234.70087.

[31]Ersoy U, Ersoy AA. "Binaların Deprem Dayanımında Mimarinin Önemi”. Yap1 Dergisi, 1992;125.58. [32]İdemen AE. "Bina Ağırlık Merkezi-Rijitlik Merkezi İlişkisini Mimari Tasarım Aşamasında Kuran Bir Uzman Sistem”. Doktora Tezi, İTÜ FBE 2003, İstanbul.

[33]Koç V. "Deprem Sonrası Ağır Hasarlı Bina Hasarlarının Sınıflandırılması". Artvin Çoruh Üniversitesi Doğal Afetler ve Çevre Dergisi. 2016.Say1 1. Sayfa 46-65.

[34] Ranke, U. (2016). Natural disaster risk management: Geosciences and social responsibility (Ffirst edi). Springer.

[35]Karaman ZT. 'Bütünleşik Afet Yönetimi' kitabı. Afet Yönetimine Giriş ve Türkiye'de Örgütlenme Bölümü, 2016.Yayın Yeri: İlkem, Basım sayısı:1, Sayfa sayısı:344, Bölüm Sayfaları:1 -36

[36]Url-6:Hyogo Framework Report, 2005-2015, http://www.unisdr.org/2005/wcdr/intergover/officialdoc/Ldocs/Hyogo-framework-for-action-english.pdf erişim 1.07.2021.

[37]Url-7:Sendai Afet Risklerin Azaltılması Çerçeve Belgesi 2015-2030, http://www.unisdr.org/we/coordinate/sendaiframework erișim 2.07.2021.

[38]Tunçel, A. Aliağa/İzmir'de (Batı Anadolu) ortam gürültüsü ve deprem senaryosu kullanılarak zemin dinamik parametrelerinin tahmini. Arab J Geosci 2021;14, 231. https://doi.org/10.1007/s12517-021-06653y

[39]Scawthorn C.and Johnson G.S..Preliminary report: Kocaeli (Izmit) earthquake of 17 August 1999.Engineering Structures. Volume 22, Issue 7,1999; Pages 727-745. https://doi.org/10.1016/S01410296(99)00106-6

[40]Ekmekcioglu ON, Demir N. Automated Detection Of Collapsed Bu1lings With Use Of Optical And Sar Images, Case Study: Izmır Earthquake On October 30th,2020. The International Archives of the Photogrammetry, Remote Sensing and Spatial Information Sciences,2021. Volume XLIII-B3-2021 XXIV ISPRS Congress (2021 edition).

[41]Kutluca AK. The İzmir City And Natural Hazard Risks, in: ESRA Conference 2006. pp. 1-22.

[42]Sozbilir H, Softa M, Eski S, Tepe Ç, Akgun M, Pamukçu OA, Çırmık A, Utku M, Ozdag M, Ozden G, Ozcelik O, Evlek DA, Cakir R, Baba A, Uzelli T, Tatar O. 30 Ekim 2020 Sisam (SAMOS) Depremi (Mw: 6,9) Değerlendirme Raporu. 2020; Izmir.

[43]30 Ekim 2020 Ege Denizi Depremi" (Pdf). Kandilli Rasathanesi ve Deprem Araştırma Enstitüsü. Erişim Tarihi: 1 Kasım 2020.

[44]Herak M. Overview of recent ambient noise measurements in Croatia in free-field and in buildings. Geofizika 2011;28:21-40

[45]Özdağ ÖC, Gönenç T, Akgün M. Dynamic amplification factor concept of soil layers: a case study in İzmir (Western Anatolia). Arab J Geosci 2015,8(11):10093-10104

[46] AFAD. (2014). Açıklamalı afet yönetimi terimleri sözlüğü. T.C.Başbakanlık Afet ve Acil Durum Yönetimi Başkanlığı. https://www.afad.gov.tr/aciklamali-afet-yonetimi- terimleri-sozlugu,

[47] Abbott, P. L. (2016). Natural disasters (10. Bask1). McGraw-Hill New York. 
[48]Işık, Ö., Aydınlığlu, H. M., Koç, S., Gündoğdu, O., Korkmaz, G., ve Ay, A. (2012). Afet yönetimi ve afet odaklı sağlık hizmetleri. Okmeydanı Tıp Dergisi, 28(2), 82-123.

[49] FEMA. (2008). National incident management system. FEMA. 